\title{
P-DELTA ANALYSIS OF MULTI STORY RC BUILDING
}

\author{
Rajath R T $\mathbf{1}^{1}$, M Ramegowda ${ }^{2}$ \\ ${ }^{I}$ P.G. Student, Department of Civil Engineering, AIT, Chikmagalur, Karnataka, India \\ ${ }^{2}$ Professor and Head, Department of Civil Engineering, AIT, Chikmagalur, Karnataka, India
}

\begin{abstract}
In first order analysis of a structure both kinematic as well as equilibrium relationships are taken with respect to un-deformed shape of the structure. But this does not consider the load which caused due to deflection of the structure. For stability design of a structure second order analysis is required which counteracts equilibrium and kinematic relationship of a structure. In a deformed structure in addition to the applied loads many additional loads due to deformation which develops second order or Pdelta effects in the structure. In the present study seismic analysis and wind load analysis of a multi -storey RC building with and without P-Delta effects is analysed by using ETABS structural analysis software. The seismic zone factor of 0.36 is considered which falls under Zone-V. From the analysis, both the displacement and drifts with respect to earthquake loads are minimum when compared with earthquake load with P-delta effects.
\end{abstract}

Keywords: P-delta, displacement, drifts and lateral load.

\section{INTRODUCTION}

When the structural elements are subjected to axial load, PDelta effects occur in the structure. It is one of the second order effects which corresponds to the load imposed on the structure with respect to deformation. It is a second order effect which is related with the displacement and the axial load amount applied. P-Delta is a non-linear effect that occurs in every structure where elements are subject to axial load. P-Delta is actually only one of many second-order effects. It is a genuine "effect" that is associated with the magnitude of the applied axial load (P) and a displacement (delta).

\section{P- $\triangle$ EFFECT}

In structure P- $\Delta$ effect generally arises due to the direct action of lateral loads where the deformed structure shape is a dominating factor in the structure at state of equilibrium. In second order analysis this kind of effects are taken care when the elements are in damaged condition. Vertical loads in high rise buildings on their way through along the elements of the structure produces additional loads at deformed parts. This additional load is not taken into consideration for the analysis of the structure. Accurate mathematical model of the structure is considered for analysis in order to study effects of P-Delta.

Second-order analysis when accounting for P-Delta combines two effects to reach a solution:-

(i) Theory of large displacement: - In this theory both forces and moments due to deformed shape of structure and also members are considered.

(ii) Stress stiffening: - In this the effect of axial load on structure stiffness is seen. Normally tensile loads straighten the geometry of an element this increases the stiffness whereas compressive loads accentuate deformation which in turn reduces the stiffness of the structure.

\section{LITERATURE REVIEW}

Farzad Naeim et al., (2001), reported the difficulties due to drift and lateral solidity of a structure. At the early stages of design development itself the drift and lateral stability plays an important role in the designing of the structure. In tall buildings torsion is the main contributor for the structural response with respect to different load combinations. [7]

Mallikarjuna B.N et al., (2014), presented P-Delta analysis is compared with linear static analysis. In this study, a 18 steel storey has been selected. The mathematical model is analysed by structural analysis software STAAD Pro 2007 with P-Delta effect consideration. [1]

Anuj Man Shakya., (2011), carried out the effects of Pdelta on steel moment frames with decreased beam section connection. Dog bone connection is called reduced beam section. [5]

Yousuf Dinar et al., (2013), focused on six different types of structures for the analysis with different number of stories. Non-linear method of P-delta analysis is used and it is carried out by P-delta analysis both $\mathrm{P} \mid$-delta analysis and linear static analysis are important for RC buildings. [6]

Rafael Shehu et al., (2014), focused to make submission to the P-delta problem and ductility in seismic design ductility is important parameter. For safe design seismicity remains fundamental premise. Design is based on the recognition of the structure deformation shape. [2]

Table-1 Details about the building

\begin{tabular}{|l|l|l|}
\hline Sl no & Structure details \\
\hline 1 & Number of stories & 13 \\
\hline 2 & Ground floor height & $5 \mathrm{~m}$ \\
\hline 3 & Floor to floor height & $3 \mathrm{~m}$ \\
\hline 4 & Beams & RC $0.3 \mathrm{~m}^{*} 0.6 \mathrm{~m}$, \\
\hline
\end{tabular}




\begin{tabular}{|l|l|l|}
\hline & & $0.3 * 0.23 \mathrm{~m}$ \\
\hline 5 & Column & $\begin{array}{l}\mathrm{RC} 0.3 \mathrm{~m} * 0.6 \mathrm{~m}, \\
0.6 * 0.23 \mathrm{~m}\end{array}$ \\
\hline 6 & Slab thickness & $0.125 \mathrm{~m}$ \\
\hline 7 & Live load & $5 \mathrm{kN} / \mathrm{m}^{2}$ \\
\hline 8 & $\begin{array}{l}\text { Live load after } \\
\text { applying reduction } \\
\text { factor for } \\
\text { earthquake case }\end{array}$ & $\begin{array}{l}5 \times 0.25=1.25 \\
\mathrm{kN} / \mathrm{m}^{2}\end{array}$ \\
\hline 9 & Roof live load & $2 \mathrm{kN} / \mathrm{m}^{2}$ \\
\hline 10 & Seismic zones & $\mathrm{V}$ \\
\hline 11 & Zone factor & 0.36 \\
\hline 12 & Importance factor & 1 \\
\hline 13 & Soil type & Medium (II) \\
\hline 14 & $\begin{array}{l}\text { Response reduction } \\
\text { factor }\end{array}$ & $\begin{array}{l}5(\text { special moment } \\
\text { resisting frame, } \\
\text { SMRF) }\end{array}$ \\
\hline 15 & Material used & M20, Fe 415 \\
\hline 16 & Damping & $5 \%$ \\
\hline
\end{tabular}

\section{DETAILS ABOUT THE STRUCTURE}

The plan of the proposed building is shown in Fig-1 and elevation is shown in Fig-2

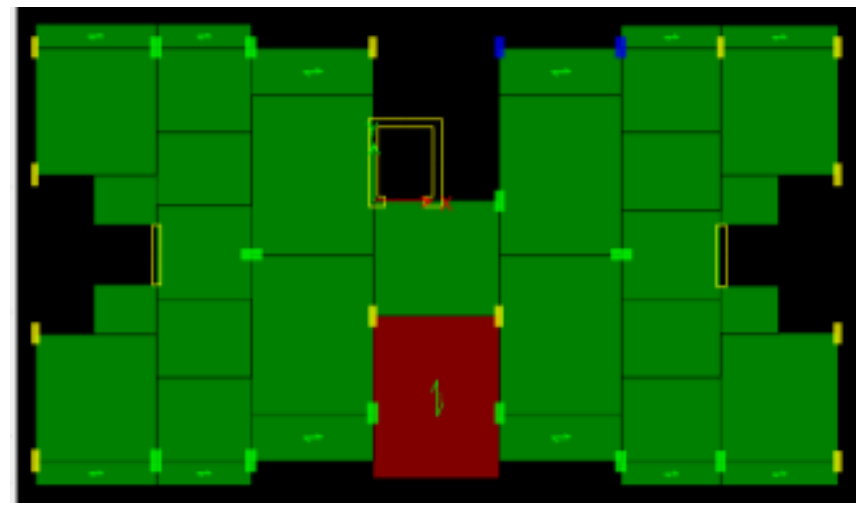

Fig-1: Building Plan

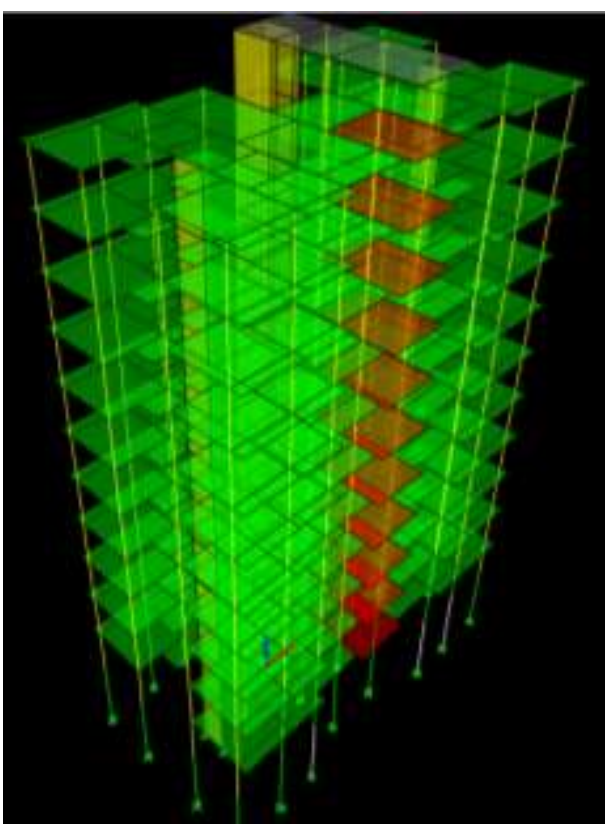

Fig-2: Building Elevation

\section{RESULTS AND DISCUSSION}

Along the height of the building auto lateral load for the earth quake load is shown in fig-3 Storey height is plotted in $\mathrm{Y}$-axis and lateral force is plotted in $\mathrm{X}$-axis

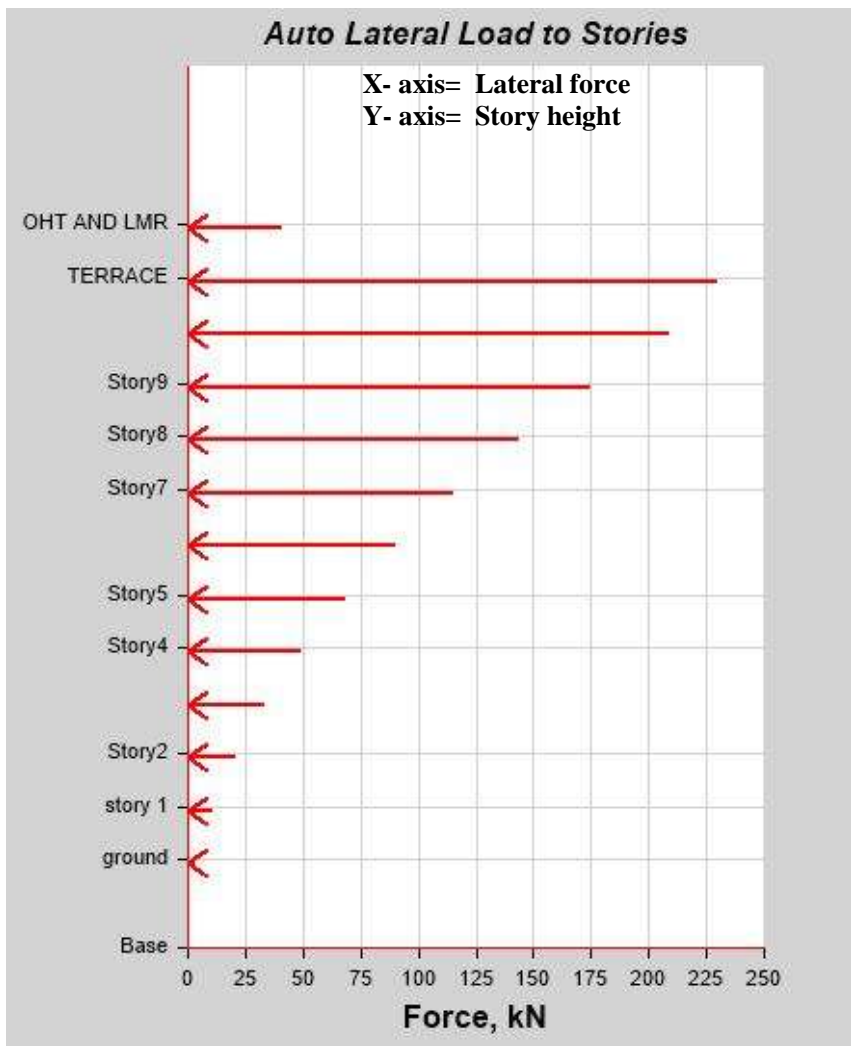

Fig-3: Auto lateral load verses storey height due to earth quake load in general

For earth quake load case the value of axial force are tabulated in table 1. Maximum axial force is seen in the terrace and minimum lateral force is seen at ground floor.

Table-1: Auto lateral load for earth quake

\begin{tabular}{|l|l|l|}
\hline Story & Elevation $(\mathbf{m})$ & Lateral load $(\mathbf{k N})$ \\
\hline Oht and $\mathbf{l m r}$ & 41 & 40.6999 \\
\hline Terrace & 38 & 230.2786 \\
\hline Story 10 & 35 & 209.4379 \\
\hline Story 9 & 32 & 175.073 \\
\hline Story 8 & 29 & 143.488 \\
\hline Story 7 & 26 & 115.4204 \\
\hline Story 6 & 23 & 90.327 \\
\hline Story 5 & 20 & 68.2961 \\
\hline Story 4 & 17 & 49.3469 \\
\hline Story 3 & 14 & 33.4928 \\
\hline Story 2 & 11 & 20.7709 \\
\hline Story 1 & 8 & 11.1086 \\
\hline Ground & 5 & 3.2841 \\
\hline
\end{tabular}

Storey displacement with respect to earth quake load without P-delta is shown in fig-4. Storey height is plotted in $\mathrm{Y}$-axis and storey displacement is plotted in $\mathrm{X}$-axis. 


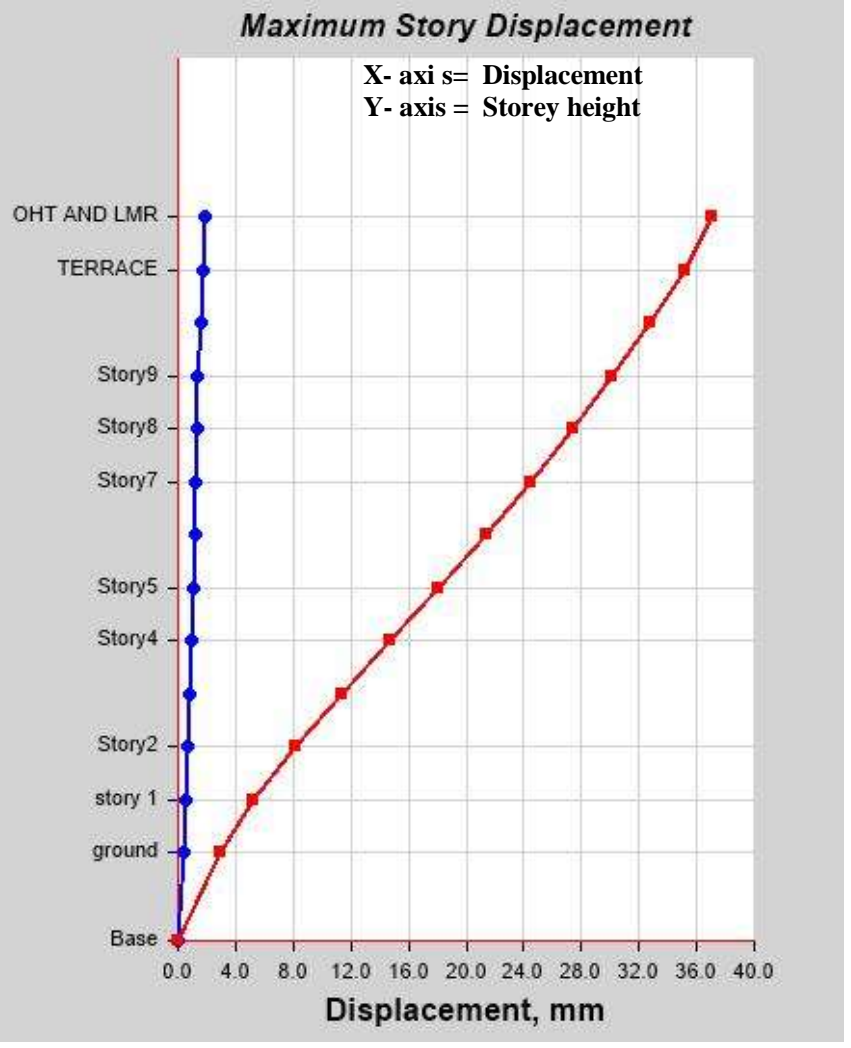

Fig-4: Displacement verses storey height due to earth quake load without P-delta effects

At the overhead tank and lift machine room the maximum storey displacement is seen and at ground floor minimum displacement is seen as shown in table- 2 .

Table-2 Storey displacements

\begin{tabular}{|l|l|l|l|}
\hline Story level & $\begin{array}{l}\text { Height } \\
(\mathbf{m})\end{array}$ & $\begin{array}{l}\text { X direction } \\
(\mathbf{m m})\end{array}$ & $\begin{array}{l}\text { Y direction } \\
(\mathbf{m m})\end{array}$ \\
\hline Oht and lmr & 41 & 1.8 & 37.1 \\
\hline Terrace & 38 & 1.7 & 35.1 \\
\hline Story10 & 35 & 1.6 & 32.7 \\
\hline Story 9 & 32 & 1.4 & 30.1 \\
\hline Story 8 & 29 & 1.3 & 27.4 \\
\hline Story 7 & 26 & 1.2 & 24.5 \\
\hline Story 6 & 23 & 1.1 & 21.4 \\
\hline Story 5 & 20 & 1.1 & 18.1 \\
\hline Story 4 & 17 & 0.9 & 14.8 \\
\hline Story 3 & 14 & 0.8 & 11.4 \\
\hline Story 2 & 11 & 0.7 & 8.2 \\
\hline Story 1 & 8 & 0.6 & 5.2 \\
\hline ground & 5 & 0.4 & 2.9 \\
\hline
\end{tabular}

For the eart quake load storey displacement with P-delta effects along the height of the building is shown in figure-5. The storey height is plotted in Y-axis and storet displacement is plotted in $\mathrm{X}$-axis.

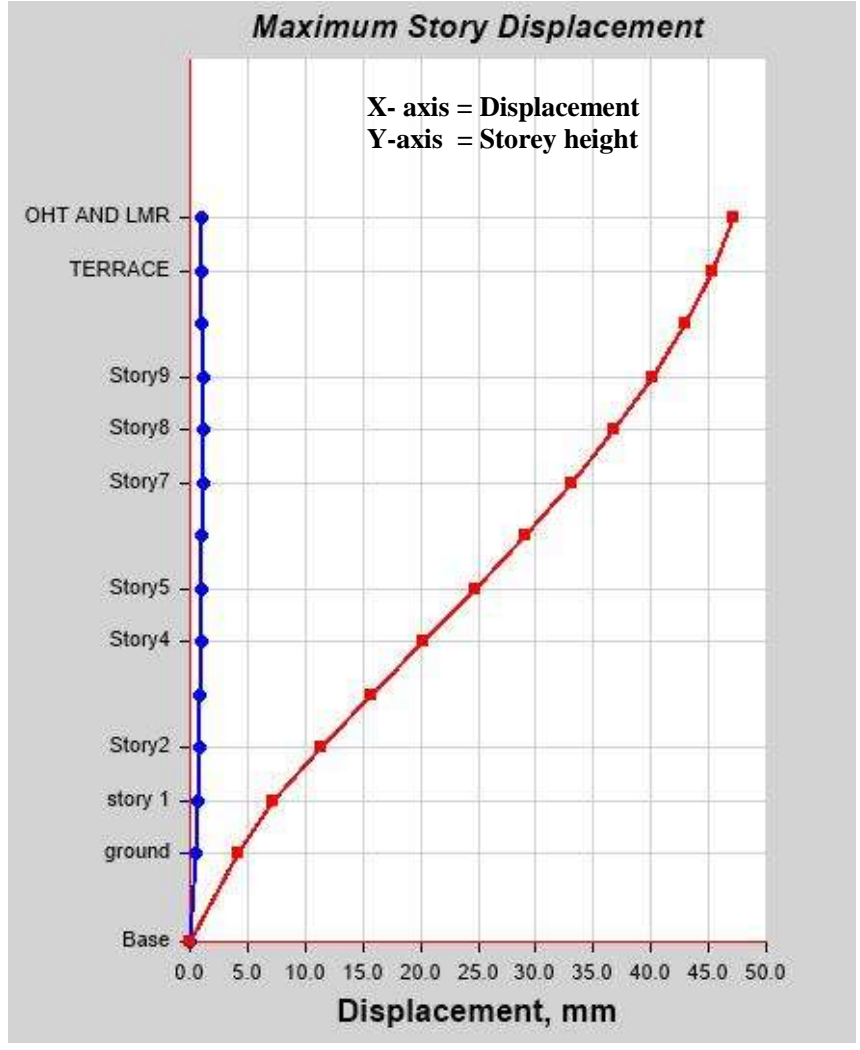

Fig-5: Displacement verses storey height due to earth quake with P-delta effects

At the over head tank and left machine room maximum storey displacement is seen and the minimum storey displacement is seen at ground floor as shown in table-3.

Table-3: Storey displacements

\begin{tabular}{|l|l|l|l|}
\hline Story level & $\begin{array}{l}\text { Height } \\
(\mathrm{m})\end{array}$ & $\begin{array}{l}\text { X direction } \\
(\mathrm{mm})\end{array}$ & $\begin{array}{l}\text { Y direction } \\
(\mathrm{mm})\end{array}$ \\
\hline Oht and lmr & 41 & 0.9 & 47.1 \\
\hline Terrace & 38 & 1.1 & 45.4 \\
\hline Story 10 & 35 & 1.1 & 43 \\
\hline Story9 & 32 & 1.1 & 40.1 \\
\hline Story8 & 29 & 1.1 & 36.8 \\
\hline Story7 & 26 & 1.1 & 33.1 \\
\hline Story6 & 23 & 1.1 & 29.1 \\
\hline Story5 & 20 & 1 & 24.7 \\
\hline Story4 & 17 & 1 & 20.3 \\
\hline Story3 & 14 & 0.9 & 15.8 \\
\hline Story2 & 11 & 0.8 & 11.4 \\
\hline Story 1 & 8 & 0.7 & 7.2 \\
\hline Ground & 5 & 0.5 & 4.2 \\
\hline & & &
\end{tabular}

Displacements are maximum in earth quake load with Pdelta effects and displacements are minimum in earth quake load without P-delta effects as shown in chart-1. 


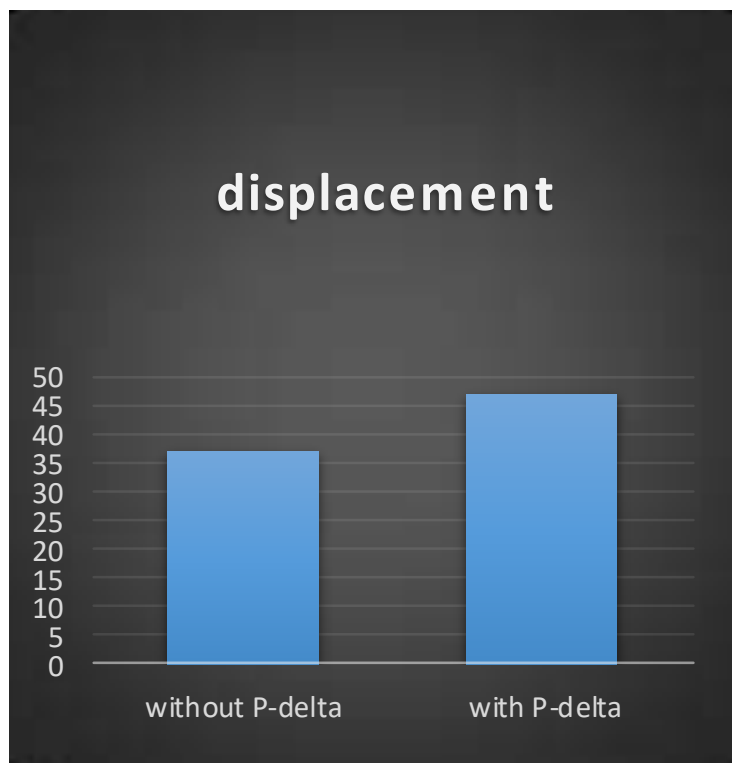

Chart-1: Comparison of roof displacements between the results.

\section{CONCLUSION}

P-delta investigations and linear static analysis are carried out for 13 storey RC framed structure using ETABS. On the basis of results obtained, following conclusions are drawn.

- Displacements with respect to earthquake load with Pdelta effects are maximum when compared with earthquake load. This concludes P-delta effects have more effect in designing of a structure rather than first order effect.

- We can minimize pounding action of two tall buildings with roof displacements.

- Storey displacement values for all the load cases are within the permissible limit.

\section{REFERENCES}

[1] Mallikarjuna B.N, Ranjith A(2014), "Stability analysis of steel frame structures: p-delta analysis", IJRET, Vol.03 Issue: 08,Aug-2014, pp 36-40.

[2] Rafael Shehu(2014), "The $p$ - $\delta$-ductility effect : overview the effect of the second order in the ductile structures" European Scientific Journal, Vol.3,2014, pp 143-155.

[3] Prashant Dhadve, Alok Rao, Atul Rupanvar, Deokate K., Admile P.R, Dr. Nemade. P. D. (2015), "Assessment of P-Delta Effect on High Rise Buildings" IJRITCC, May 2015, Vol.3 Issue: 5, pp 3231-3236

[4] Rupali Bondre, Sandeep gaikwad (2016), “Analysis of structures with respect to linear static analysis using pdelta effects" IJARIIE Vol.2 Issue-4 2016 pp 32313236

[5] Anuj Man Shakya (2011), "P-delta effects on steel moment Frames with reduced beam section Connection" http://opensiuc.lib.siu.edu/theses

[6] Yousuf Dinar, Samiul Karim, Ayan Barua, Ashraf Uddin (2013) " P-Delta Effect in Reinforced Concrete Structures of Rigid joint” IOSR-JMCE, Vol.10, Issue 4 (Nov. - Dec. 2013), PP 42-49
[7] Farzad Naeim "Design for Drift and Lateral Stability".

[8] Prof. C. G. Konapure, Mr. P. V. Dhanshetti(2015) "Effect of P-Delta Action on Multi-Storey Buildings", International Journal of Engineering Research and Technology, Vol.4, Issue 1, January 2014.

[9] IS 1893 (Part-II and III): Criteria for Earthquake Resistant Design of Structure, Bureau of ndian Standards, New Delhi

[10] IS: 875 (Part-I)-1987 Code of pract ice for design loads (Other than Earthquake) for buildings and structures, Bureau of Indian Standard, New Delhi, India.

[11] IS 875 (Part-II)-1987. Code of Practice for design loads (other than earthquake) for building and structure, PartII , imposed loads. B S, Manak Bhawan, New Delhi, India.

[12] IS 875 (Part-III)-1987, Code of Practice for design loads (other than earthquake) for building and structurell, Part III, Wind Loads, B S, Manak Bhawan, New Delhi, India.

[13] IS 456:2002 Plain and Reinforced concrete-code of practicell, B S, Manak Bhawan, New Delhi, India. 